applicant's request, nor any decline in the standards of meals served to the other prisoners. [Matthew Gibson]

doi:10.1017/So956618X1100055X

\author{
Re Scholemoor Cemetery, Bradford \\ Bradford Consistory Court: Walford Ch, January 2011 \\ Exhumation - no exceptional circumstances
}

Applying Re Blagdon Cemetery [2002] Fam 299, the chancellor held that a desire to fulfil the wish of the petitioner's mother that her husband's ashes should be placed with hers did not amount to exceptional circumstances such as to justify the exhumation and removal of his cremated remains from one cemetery to another. The chancellor held that 'a wish (however understandable) to reverse a decision made several years ago, which although regretted since was perfectly valid at the time it was made, is not sufficient, in my judgment, for these purposes'. [Alexander McGregor]

\title{
Hall and Preddy v Bull and Bull
}

Bristol County Court: HHJ Rutherford, January 2011

Discrimination - Equality Act - religious belief

The claimants brought an action against the defendants under the Equality Act (Sexual Orientation) Regulations 2007 for a declaration and damages for discrimination on the grounds of their sexual orientation. The claimants were two men who were in a civil partnership who had, by telephone, booked a double room at the defendants' hotel. The defendants ran their hotel (which was also their home) along Christian principles and their policy, which was stated in clear terms on their website but of which the claimants were unaware, was to let double rooms only to heterosexual married couples. On arrival at the hotel, the defendants refused to allow the claimants to use a double room. Both parties relied upon their rights under Articles 8 (right to respect for their private and family life) and 14 (right not to be discriminated against) of the ECHR. The defendants relied upon their right to manifest their religion under Article 9 of the ECHR. The judge accepted that the running of an hotel along Christian principles could be regarded as manifesting one's religion. The judge held that the claimants had been directly and indirectly 